\title{
LHX2 Gene
}

National Cancer Institute

\section{Source}

National Cancer Institute. LHX2 Gene. NCI Thesaurus. Code C24550.

This gene plays a role in transcriptional regulation and has been implicated in the control of differentiation. The gene is also postulated to be involved in the development of neural and lymphoid cells. 